\title{
Islam in Imperial China: Sinicization of Minority Muslims and Synthesis of Chinese Philosophy and Islamic Tradition
}

\author{
FAUZIAH FATHIL \\ Department of History and Civilization, Kulliyyah of Islamic Revealed Knowledge and Human \\ Sciences, International Islamic University Malaysia, 53100 Kuala Lumpur, Malaysia \\ fauziahfathil@iium.edu.my
}

Published online: 15 August 2019

To cite this article: Fauziah Fathil. 2019. Islam in imperial China: Sinicization of minority Muslims and synthesis of Chinese philosophy and Islamic tradition. KEMANUSIAAN the Asian Journal of Humanities 26(Supp. 1): 167-187. https://doi.org/10.21315/kajh2019.26.s1.9

To link to this article: https://doi.org/10.21315/kajh2019.26.s1.9

\begin{abstract}
Even though China is nowhere near the heartland of Islam, the country is not a stranger to the religion brought by Prophet Muhammad (pbuh). In fact, Islam had reached China as early as 7 th century $\mathrm{CE}$ and achieved its zenith during the era of the Ming Dynasty (1368-1644 CE), also known as the "Golden Age of Islam" in China. Not only were Muslims during the Ming era generally accepted by majority Chinese whose affiliations were predominantly Confucianism, Buddhism and Daoism, Islam was legally recognised by the imperial government. The number of Islamic institutions such as mosques and learning centres increased, and so did the number of Muslim population in the country. In administration and politics, the Muslims equally received their share while Muslim intellectuals and scholars found themselves appreciated and acknowledged by Chinese rulers for their contributions. Nevertheless, as with minorities of other countries, the Muslims in China were subject to assimilation or integration into the culture of the majority, i.e., Han Chinese. This policy known as "sinicization" consequently affected Muslims in many ways, leading to changes in their lifestyle, custom and tradition. Using qualitative approach and library research method, this paper aims to assess the underlying reasons for the sinicization of Chinese Muslims apart from the obvious political necessity of the Chinese imperial government, and the effects of the process on the Muslim community. On the latter, focus will be given to Muslims' attempt to synthesise Chinese philosophy and Islam during the imperial era (618-1912 CE) as it served to project the peaceable nature of Islam hence enabled Muslims to preserve their distinctive Islamic identity and tradition amidst the predominant non-Islamic cultural setting. In other words, the synthesis which was pioneered by Chinese Muslim scholars, particularly of the Ming until the Qing era, not only prevented full assimilation of Muslims into local Chinese culture but also ensured the survival of Islam and its tradition in China until the modern period.
\end{abstract}

Keywords and phrases: Muslims in China, Islam in China, Islam in imperial China, sinicization of Muslims, Muslim minority in China 


\section{Introduction}

Islam first reached China during the Tang era (618-907 CE). Over the centuries, Islam slowly gained a foothold in China that by the last imperial period of Qing or Manchu dynasty (1644-1912 CE), Islam and Muslims gained recognition as a minority religion and communal group in China. Ever since the Tang era, Muslims had been appointed to high ranking administrative posts as court advisors, governors, etc. Similarly, in the army, some Muslims were entrusted with important positions as military leaders and generals. The contributions of Muslims can also be noted in the realm of science and knowledge. Not only did Muslim scholars make lasting impacts through the discovery of new ideas for which reason they were appreciated by the Chinese people and government, but more importantly, their works contributed to the spread and preservation of the Islamic tradition among the Chinese Muslim community through the synthesis of Chinese philosophy and Islam. Perhaps, it is not too much to say that without such effort, Islam would not have been readily accepted or tolerated by the people and authorities in China over the course of its history. The fact that Islam was treated fairly well throughout the imperial rule as opposed to few foreign faiths such as Catholicism, Tibetan Buddhism and Manichaeism (a Persian belief) deserves some attention as it raises the question of why this was so. The answer partly lies in the synthesis of Confucian philosophy and Islam by Chinese Muslims that began primarily from the Ming era.

In order to understand when and why the effort to synthesise Chinese philosophy and Islamic tradition was made, one has to assess the prevailing situation in China noting some major turning points in the history of the country and the position of Muslims as a minority group living in a non-Islamic milieu. As a minority community, one continuous and pressing issue experienced by Muslims in imperial China was assimilation into majority non-Muslim culture also known as "sinicization". It is however, erroneous to think that the sinicization was merely an outcome of government policies since it was also partly due to the very existence of Muslims in the country itself where centuries of mingling and socialising with the non-Muslim majority led to gradual change in their way of life as accommodation of popular or dominant culture set in. Unlike government policies which are sometimes unwelcoming, assimilation of Muslim minority due to long contact with mainstream culture is naturally inevitable.

With that in mind, using qualitative and library research methods, this paper will look at various factors which contributed to the sinicization of Muslims in China, including imperial government policies towards Islam and Muslims. Attention will then be given to the stimulus for synthesis by Muslim intellectuals and scholars 
followed by some notable ideas introduced by them as a result of the synthesis between Chinese philosophy and Islamic principles. Instead of drawing attention to various changing aspects of Muslim lifestyle, this paper will however, in view of the limited space, highlight mainly the synthesis done by Muslim scholars in reconciling Chinese ideas of Confucianism with Islam, best manifested in an Islamic school of thought known as the Gedimu School.

\section{Literature Review}

Unlike literature on Islam in other East Asian nations like Japan and Korea, a lot has been written on Islam in China in spite of it being a minority religion. It is not difficult to understand why. Not only does Islam in China have a long history dated back to the early century of Islam, the sheer number of Muslim minority in China which is about 23 million also attracts the attention of academicians and scholars as it is comparatively huge to what is normally implied as a "minority" group. Equally fascinating is the distinctive identity of Muslims in China which withstands the test of time.

On Islam and Muslims in China, the work of Donald D. Leslie is very informative as it discusses the origin and development of Islam from the Tang until Qing era (Leslie 1998). While Leslie does touch on the sinicization or assimilation of Muslims into Chinese culture during different eras in Chinese imperial history, the outcome of the process however, one of which being the synthesis of Chinese philosophy and Islamic ideas by Muslim scholars is not sufficiently covered. This is understood since the work in dealing with the integration of Muslims into local culture focused mainly on government policies towards Islam and Muslims in the country. On the other hand, his work entitled Islamic Literature in Chinese (Leslie 1981) is more on the reconciliation between Chinese and Islamic ideas while the sinicization process was side-lined. This paper attempts to bridge the two together namely sinicization and synthesis of ideas, hence establishing a clear connection as to how the former process contributed to the latter.

James Frankel's work discusses in great length the synthesis embarked upon by Muslim scholars with the main aim to obtain legitimacy and recognition for Islam from the imperial government instead of being viewed as a threat (Frankel 2008). The details provided by Frankel regarding the works and ideas of Muslim scholars prove to be comprehensive as he extensively dwelled on the Chinese Han Kitab which refers to a body of literature on Islamic beliefs and practices written in classical Chinese. Given his emphasis on the synthesis contained in Han Kitab, not much information is available on the sinicization or assimilation of Muslims in China. Again, this is where this paper endeavours to link the sinicization to the 
synthesis by Muslim scholars whose interest lies in the preservation of a distinctive Islamic identity amidst increasing pressure for assimilation into the larger Chinese population.

Another relevant work is by Raphael Israeli where he narrates the development of Islam and Muslims as a minority culture and group in China beginning from the imperial era until modern times (Israeli 2002). Concerned with the relations between Muslim minority and majority Chinese population, the author tackles the ideological, philosophical and ethnic disputes between them, as well as feuds between different Muslim sects. Furthermore, the work uncovers the gradual sinicization process experienced by Muslims and its outcomes, one being the accommodation of Islam by the mainstream culture, particularly in modern day China. This paper on the contrary, in dealing with sinicization, focuses more on Muslims' efforts to reconcile between Chinese and Islamic ideas during the imperial era.

Michael Dillon's work provides valuable information on minority Muslims known as Hui, the descendants of early Muslim migrants to China (Dillon 1999). Starting with early history of Islam in China which saw the migration of Muslims from the Middle East and Central Asia during the imperial era, Dillon continues with the settlement and growth of Muslims in the country up to the 20th century. Using mainly Chinese-language Muslim sources to retrieve information, Dillon explains the role of religion among the Hui Muslims as well as the development of various Sufi orders in China. While he does discuss the sinicization of Hui Muslims, his treatment of their response to that process is more concerned with the relations between Muslims and the Chinese government which sometimes involved uprisings and rebellions by the former. From this discussion he concludes that although Muslims managed to preserve their distinctive identity, they failed to form a united force against the Chinese authorities. Unlike Dillon, this paper aims to examine a different kind or rather subtle response by Muslims that is the synthesis of Chinese and Islamic ideas in preserving their identity and at the same avoiding conflicts with the Chinese authorities.

As with Dillon, Jonathan N. Lipman also discusses the development of Islam from the Tang era until the 20th century including the Sufi groups particularly in northwest China but using both Chinese and Western sources (Lipman 1997). His variety of sources lead him to raise some fascinating questions related to Muslims in China, hence making his work more critical and at the same time his arguments more convincing. While Lipman does explain the issue of sinicization of Hui Muslims, his attention is directed to the role of religion, language and ethnicity as important factors which enabled Muslims to maintain their identity. 
The same factors are pointed out in relation to the violent outbreaks either between Muslims and the Chinese authorities or between different conflicting Sufi groups. Given the author's focus on conflicts and feuds, little attention is given to Muslim scholars' effort to synthesise Chinese and Islamic teachings. Taking a different approach from Lipman, this paper endeavours to illustrate that the preservation of Hui Muslims' identity is a result of reconciliation between minority and majority cultures which proves to be peaceful and non-violent.

On the synthesis of Islam and Confucianism, the work of Petersen is useful as it highlights the adaptability of Islam to Chinese traditions (Buddhism, Daoism and particularly Confucianism) as embodied in the Han Kitab resulting from the efforts done by a small group of Muslim scholars (Petersen 2018). The synthesis which fully emerged during the Ming Dynasty, according to the author, was meant to construct a meaningful religious tradition that the Muslim community in China could fully understand. Focusing mainly on re-interpretation of religious and philosophical concepts of Islam and Chinese traditions, the work is very relevant to the Gedimu School discussed in this paper, yet unsurprisingly, left political issues and government policies towards the sinicization of Muslims untouched.

Similarly, Tontini illustrates the interconnected relationships between Islam and Chinese tradition concentrating however, on the compatibility between Islamic law and Chinese state law (Tontini 2016). Starting with Tianfang dianli (Norms and Rites of Islam) - the most influential Chinese work on Islamic law published by a prominent Hui scholar, Liu Zhi in 1710 - the author studied the development of Islamic legal thought in China over three centuries, i.e., from 18th until 21st century against the backdrop of different political settings in China, ranging from monarchies, republics and communist state. The limited scope of the study, where it focuses mainly on legal aspects nevertheless, implies that it is devoid of some other traits of the sinicization of Muslims such as the various sociocultural and political factors for the assimilation of Hui Muslims into the Han culture.

\section{Research Methodology}

In undertaking this research, library-based methodology is used in seeking various contributory factors for the sinicization of Muslims in China and the synthesis made by some Muslim scholars. Additionally, the methodology is mainly analytical and qualitative making use of available materials on Islam and Muslims in China in looking for wide-range observations and conclusions. Starting with the coming of Islam where factors for the expansion and spread of Islam are briefly explained, the discussion continues with the sociocultural and political factors leading to the sinicization of Muslims during the Chinese imperial period. What followed next is 
the synthesis initiated by Muslim scholars of the Ming era of Chinese philosophy particularly Confucianism with Islam, an effort which by itself is a form of reaction by Muslims to legitimise and preserve their religion in a majority non-Muslim country, i.e., imperial China.

\section{The Coming of Islam to China}

Islam was first introduced to China during the era of the Tang Dynasty (618$907 \mathrm{CE})$ after which there were four dynastic rules namely, Song Dynasty (960-1279 CE), Mongol Yuan Dynasty (1271-1368 CE), Ming Dynasty (1368$1644 \mathrm{CE}$ ) and finally Qing or Manchu Dynasty (1644-1912 CE). During the imperial period from Tang until Qing Dynasty, Islam used to be referred to with different names such as "Tajir", "Tajik religion", "Hui religion", "Hui Tajik religion", "Hui denomination", "Arabian religion", "Dashi fa" (Law of the Arabs), "Hui jiao" (Hui Teaching), "Religion of Huihui", "Islamic religion" and "Mohammedanism". It was not until post-imperial period, i.e., 1956 that "Islam" was officially accepted to replace "Hui religion". As for Muslims in China, several terms were used for instance, "Dashi" to refer to Arabs, "Hui" or "Huihui" for descendants of Arab or Persian origins and local Chinese, "Dungan" and "Panthay" for Muslims in Yunnan. In ancient Chinese records, apart from Dashi (for Arabs), the earlier Muslim settlers were also known as "Fan ke" ("fan" means "foreign") and "Buosi" (for Persians). It was not until the mid-1950s that the Hui Muslims were officially recognised as one ethnic group by the government of the People's Republic of China (PROC) (Gunaratna, Acharya and Pengxin 2010).

Islam was believed to first reach China in 7th century AD during the period of Caliph Uthman al-Affan when Sa'd ibn Abi Waqqas was sent on a diplomatic mission to the country (Leslie 1998; Owadally 2006). Since then Islam gradually spread in China through trade, diplomatic ties, wars, social movement or migration, da'wah (invitation to Islam) mission which include Sufi preaching as well as political or administrative reasons. Of these factors, trade contributed the most to the cause of expansion of Islam in China. Not only did the famous Silk Route which connected the country with the Muslim world in Central Asia and the Middle East bring into China valuable commodities, but also Islamic faith to its people. Equally significant was maritime trade routes linking up China with the Arab world via major waterways in South East Asia and the Indian subcontinent where ships from trading ports in the Middle East sailed back and forth to China for silk, paper and porcelain. As the number of Muslim traders in China grew and trade flourished, they were allowed to settle in major commercial cities including capital cities - throughout the imperial era, several cities had been made as the capital of China namely, Chang'an/Xi'an and later Luoyang (Tang Dynasty); 
Kaifeng and Hangzhou (Song Dynasty); Khanbaliq/Canbulac or Beijing (Yuan Dynasty); Nanjing and later Beijing (Ming Dynasty); and Beijing and Shenyang (Qing Dynasty). The open-door policy of the Yuan Dynasty in particular contributed to extensive trade between the Muslim world and China and coupled with Yuan's flexible policy on migration consequently led to further expansion of Islam in the country. During the Song Dynasty, Muslims or Arabs were said to dominate trade in the southern coast of China to the extent that the post of Trade Superintendent was continuously held by Muslims.

Diplomatic missions initiated during the time of Caliph Uthman were continued by the successive Muslim governments in the Middle East and Central Asia, leading to continuous flow of Islamic influence into China. Apart from trade and diplomatic missions, wars unexpectedly also generated positive results. In about 756-762 CE, some Turkic Uyghurs and Arab troops were said to have assisted Tang emperors, Emperor Suzong and later his son Emperor Daizong to suppress the An Lushan rebellion. Muslim sources claim that of this Muslim army, 4,000 soldiers settled in north China marrying Chinese women (Leslie 1998) hence, contributed to the gradual formation of the Muslim community in the country. The positive outcome did not abate here as the Tang government, in return for the military help, became more open towards Islam and Muslims, allowing them to migrate and settle in China. In fact, many Muslim Turkic groups of Central Asia were later recruited into Tang's state army, and this trend of hiring Muslims of that region for military purpose was continued by rulers of the successive Chinese dynasties.

The migration of Muslims into China which began since the Tang period and continued into the following eras also contributed to the expansion of Islam. While some Muslims migrated for economic reasons, i.e., to do trade, some did so, as mentioned earlier, after having been involved in some military expeditions in the country or due to being hired as soldiers by the Chinese authorities. It is worth mentioning that in relation to the second reason, not only were Muslims seen by Chinese rulers as efficient and professional soldiers, but their presence at certain strategic places could prevent attacks on China by its enemies. This is what the Song ruler, Emperor Shen-tsung (Shenzong) had in mind when he invited 5,300 Muslims from Central Asia to migrate and settle in an area near Beijing in $1070 \mathrm{CE}$. His idea was to have a Muslim settlement as a buffer zone between his domain and a hostile neighbouring kingdom, the Liou in the northeast. During their stay in China, the Muslim migrants also served as soldiers in the Song military campaign against the Liao. Such a defensive plan must have worked that in 1080 $\mathrm{CE}$, a greater number of Muslims from Central Asia including women were invited to cross over the border and settle in north and northeast regions adjacent to the Liao kingdom (Israeli 2002). 
As with other countries, Islam also spread through $d a$ 'wah missions spearheaded by Muslim missionaries or $d a{ }^{\prime} i$. Some belonged to Sunni schools and some were associated with Sufism. The coming of Sufi preachers however, was late. It was not until the mid-17th century CE that they made their presence felt in China. The first Sufi sect to operate in China is the Qadariyya introduced by Khawja Hassan, who was believed to be a descendant of Prophet Muhammad (pbuh) in the second half of the 17th century CE. Active propagation of Islam took place particularly during the Ming era, where as a result of Ming's favourable policy towards Islam, Muslim missionaries began to travel afar throughout China and spread the new religion among its people (Dillon 1999).

As for administrative or political factor, the actions of the Yuan Dynasty in particular testified to the spread of Islam in China due to that reason. Having created a huge empire stretching from Japan Sea to Aegean Sea, the Yuan rulers resolved to employ capable Muslims - particularly of Persia and Central Asia - to administer its domain in China. This is to prevent resistance from the majority Chinese population (mainly of Han ethnicity) against their rule had they appointed administrators and governors from amongst the same group. The hatred felt by the Han who formed the biggest ethnic group towards the Mongols whom they saw as non-Chinese unworthy of ruling China provided more reason for the Mongols to appoint non-Hans as government officials. As prevailed in China, the same approach was applied by the Mongols in the occupied Muslim territories where Confucian trained-Chinese administrators were despatched from Peking to rule over Muslim communities in Persia and Central Asia (Buell 1979).

In due course, Muslims slowly increased in number and despite few imperial edicts prohibiting inter-marriages between Muslim settlers and local women issued by Tang and Song rulers, the laws proved to be unworkable. Inter-marriages between Muslims and local Chinese women of Han ethnic group inevitably took place leading to the establishment of a growing Muslim community, particularly in areas adjacent to Chinese-Muslim borders. The Muslims and their descendants were commonly known as "Hui" or "Huihui" among the local Chinese. Ethnicity wise, the Muslims in China however, consists of different Turkic groups such as Uyghur, Kazakh, Kirgiz, Tajik, Uzbek and Tatar, and Hui (descendants of Muslims of Persian, Arabian and Central Asian origins and Han Chinese). Other ethnic groups include Dongxiang, Salar, Baoan, Han, Mongolian, Tibetan, Bai, Dai, etc. If previously "Hui" was used in Chinese sources to refer to all Muslims of various origins, in present China the term specifically refers to descendants of Arab, Persian and Central Asian Muslims and Han Chinese. Currently, the number of Muslims is estimated at around 23 million or 1.7 percent of total Chinese population of 1.3 billion with heavy concentration in northwest and northeast regions namely 
Xinjiang, Ningxia, Gansu and Qinghai. Substantial number of Muslim population can also be found in provinces of Henan, Hebei, Shandong and Yunnan. In terms of religious affiliations, while they are all Muslims, they belong to different schools with the largest number being that of the Hanafi Sunni School. Other sects include the Shafi'i Sunni School, Xidaotang, Yihewani, Wahabbis or Salafi and some Sufi groups. Known among the local Chinese as "gongbei", leading Sufi sects in China include the Khafiyya and Jahriyya of the Naqshbandi order, the Kubrawiyya and Qadiriyya (Junqing 2010).

\section{Sinicization of Hui Muslims: Assimilation of Chinese Culture}

Sinicization refers to a process of assimilation of dominant Chinese or Han culture by Hui Muslims who formed the minority group in China. While the process of assimilation is central in the sinicization of Muslims, the term is inconclusive having been also described to mean localisation, nationalisation, integration, acculturation, amalgamation, etc. In spite of the diverse meanings, all the processes mentioned above point to the adoption by the minority in one or another, of the culture of the majority and that they entail full or partial assimilation, as well as quick or gradual changes. One definition by Dictionary of Sociology summed up assimilation as "the process by which different cultures, or individuals or groups representing different cultures, are merged into a homogenous unit" and that "ordinarily, the modifications must be made by the weaker or numerically inferior group" (Fairchild 1944).

Additionally, assimilation is very often not a one-way process since it involves minority groups taking on the culture of the dominant group while the latter accommodating the former into its own. In some cases, the assimilation is natural or inevitable particularly if it involves close proximity or long and cordial contact with the majority. In the case of China, since the Han culture is the most dominant, coupled with centuries of contact with the Hui Muslims who are numerically inferior, the latter consequently took on some cultural aspects of the former. Another significant point to consider is that assimilation could also happen either spontaneously or a result of a series of policies enforced by the ruling authorities. Looking at what happened in China, there had been such attempts to assimilate or integrate the Muslims through the issuance of imperial edicts and laws by the ruling authorities.

While sinicization or assimilation of Hui Muslims into the Han Chinese culture during the imperial period did take place, at varying degrees under different imperial governments, the process was by no means full or complete. Instead of embracing the Han culture fully, the Hui Muslims until this present day continuously uphold 
their own distinctive culture particularly in matters related to religious duties and rituals. Despite the change in their outer appearances and language (previously the Muslims spoke either Arabic or Persian), Islam remains to be practiced, mosques continue to be centres of worship while Islamic knowledge and Arabic taught and learned. To understand why or what caused the sinicization fell short, the answer perhaps lies in the distinctive trait of Islam itself, where once embraced it would be difficult for the adherents to abandon it fully as Islam encompasses all aspects of their lives. Interestingly, a view that the Chinese by nature never completely abandon their root or identity (Leslie 1998) perhaps also deserves some attention since the Hui Muslims were generally half Chinese being descendants of early Muslim settlers and local Han Chinese. This explains why the Hui readily accepted some aspects of the Han culture yet remained steadfast in their Islamic faith, the religion of their Muslim forefathers.

Throughout the imperial rule, China's government policy towards Islam and Muslims was generally tolerant and flexible. While there had been several incidents in which Muslims were suppressed by the authorities for instance, following the outbreak of the Panthay Rebellion (1856-1873 CE) and Dungan or Tungan Rebellion (1862-1877 CE), which occurred during the Manchu or Qing era, the underlying reasons were mainly political rather than religious. During these events, some of the Muslims who rebelled sought to end the Qing Dynasty and replace it with a Chinese rule since the Manchus like the Mongols were seen as outsiders therefore, unfit to rule China. Naturally, it is no surprise to see that apart from the Muslims, the rebellions also saw the involvement of non-Muslim groups against the Qing government as they too wanted to end the Qing rule.

Apart from the desire to end the Manchu's rule, there was also an instance of Muslims wanting to secede from the central government and form independent Islamic kingdoms like during the Panthay Rebellion. Also known as Tu Wen-hsiu Rebellion after the name of its instigator Tu Wen-hsiu (1828-1873 CE), a Muslim of Han origin, the Muslim uprising broke out in south-western Yunnan province. This followed a massacre of at least 2,000 to 3,000 Muslims in Kunming who were involved in a large-scale campaign to expel the Manchus from China. The rebellion saw the foundation of a Muslim Sultanate called P'ing-nan Guo or the Pacified Southern kingdom led by Tu Wen-hsiu, who called himself Sultan Sulayman ibn 'Abd ar-Rahman. The Sultanate was finally suppressed by the Qing authorities in 1873 (Fairbank and Liu 1980). Given the political nature of the factors leading to the rebellions, it is thus, not surprising to find that there were Muslim leaders and groups who supported and joined the Qing government against the rebels as they shared no interests in the agenda of the insurgents. Among the Muslim leaders include Ma Dagui, Ma Qianling, Ma Haiyan, Ma Anliang and Ma Zhan'ao. 
Nevertheless, apart from political reasons, there were also some social and economic reasons which served as catalysts or immediate causes for the uprisings. Both the Panthay and Dungan rebellions first broke out following some economic disputes between Hui Muslims and Han individuals. The immediate reason for the Panthay Rebellion was a clash between Muslim and non-Muslim miners over the control of a silver mine in central Yunnan (Fairbank and Liu 1980). Meanwhile, the Dungan Rebellion first began following a pricing dispute over bamboo poles between a Han seller and a group of Hui Muslims (Dillon 1999). The Dungan Rebellion in particular, involved various groups and leaders of different backgrounds, some fighting against the Qing government and some fought each other over trivial issues. Also known as Tongzhi Hui Revolt among the local Chinese, it occurred in Shaanxi, Gansu, Ningxia and Xinjiang provinces. By the end of the war there was a reduction of almost 21 million people in these areas. Many left China for Russia and millions died due to war-related reasons and famines. In short, none of these incidents of conflict between the imperial government and Muslims was purely religious strife, i.e., due to government's efforts to suppress Islam and Muslims for religious reasons.

A more intriguing argument which could explain the feeling of discontent felt among the Muslims towards the government is the Manchu's policy of the mid19th century which, unlike previously, tend to favour the majority Han Chinese instead of Muslims. This is because the Manchus were in need of greater support from the majority population in facing increasing threats from Western powers. The Manchu's policy was thus seen by Muslims as a form of discrimination which in turn caused them to fight against the government.

With the exception of these unfortunate incidents, generally the Muslims were treated well by the rulers of imperial governments of China. To scrutinise the policies of each imperial government towards Islam and Muslims is not viable given the limited context of this paper. Therefore, only policies concerning the assimilation of Hui Muslims into the Chinese culture or sinicization will be highlighted in order to assess the impacts of those policies on the synthesis of Confucian philosophy and Islamic tradition by Muslim intellectuals and scholars.

As to when the sinicization of Muslims actually began, majority of records points to the Ming period and this is justifiable given the many changes that happened in the lifestyle of the Hui Muslims during that era. Though there had been several attempts by earlier rulers of the Tang, Song and particularly Yuan dynasty to regulate the lives of Muslims in China through enactment of laws, requiring them to be no different from the Han Chinese population, the effects of assimilation were however, most visible during the Ming era. Not only did Muslims during the 
Ming period adopt Chinese dress code, write religious inscriptions using Chinese scripts, speak Chinese dialects and change their names to sound more like Chinese, they also took on Chinese cultural influence in the realm of knowledge such as philosophical concepts and ideas. Several factors contributed to the sinicization during the Ming period, i.e., the Ming government's ethnic or racial policy, isolationist policy of the Ming Dynasty, accommodating attitude of Muslims towards local culture, and finally some incidents of conflict between Muslim and non-Muslim communities in China.

On the Ming's ethnic or racial policy, the integration of people belonging to various ethnic groups under centralised rule was the main goal of the Ming government. Having survived a long war against the Mongols of the Yuan Dynasty, integration in the eyes of the Ming rulers, was very crucial for the unity and survival of China in facing internal and external threats. Consequently, some laws were issued requiring Hui Muslims as with other minorities in China to adopt several cultural aspects of the Han ethnic group, to which the Ming belonged. Nevertheless, it is important to mention here that of the various minority groups Muslims were favoured by the Ming rulers, leading to the notion of the Ming's pro-Islam policy, as argued by some scholars, and that the Ming era was the "Golden Age of Islam" in China. Among the Ming emperors who displayed such a policy include Emperor Hongwu (1368-1398 CE), Yongle (1402-1424 CE), Xuande (1425-1435 CE) and Emperor Zhengde (1505-1521 CE). For instance, apart from giving orders for the establishment of a mosque at Nanjing, Emperor Xuande instructed one hundred characters of praise on Islam, Allah and Prophet Muhammad (pbuh) to be written on the walls and surfaces of the mosque. Early Islamic learning centres were first established on the southeast coast by Arab and Persian scholars. By the late Ming and Qing period, more centres were allowed to be established in areas near Xi'an, and later in south-eastern Gansu (Dillon 1999).

Apart from establishment of mosques and Islamic learning centres, other proofs of pro-Muslim policy include the employment of a substantial number of Muslims in the imperial court, administration and army, as well as patronage given by Ming emperors to Muslim scholars. There was also an issuance of imperial edicts prohibiting the slaughtering of pigs and consumption of wine. Such edicts were issued during the reign of the Ming Emperor Zhengde (1505-1521 CE). It was during his reign that numerous moves in favour of Islam and Muslims took place, some argued mainly out of his fascination with foreign Muslims. The moves include the recruitment of Muslims as court advisors, eunuchs, imperial envoys and governors, and the carving of Islamic inscriptions in Arabic and Persian scripts on court porcelain wares. Still ironically, what seemed to be Ming's pro-Islam policy was compensated by sinicization of Hui Muslims that made them consciously or unconsciously abandoning some of their own cultural traits. 
Despite what appeared to be Ming's pro-Islam policy, Muslims were subject to the integration policy of the Ming making them in due course also inclined towards the culture of non-Muslim Chinese. One such ruling towards integration was inter-marriage law requiring minorities to marry Han Chinese. The fact that the Ming belonged to the Han ethnic group explained the issuance of the law to assimilate minorities into the larger Han community. While the law was applicable to the Muslims as to other minority groups, in the case of Hui men marrying Han women, the latter would normally convert to Islam, leading to gradual increase in the number of Muslims. As for Hui women, not many Han men, due to status, chose to marry them. Before the Ming, there had also been several policies towards integration which affected Muslims. The Yuan rulers for instance, once issued an edict prohibiting Muslims from slaughtering animals for food and performing circumcision. The first prohibition was nevertheless, eventually abandoned as it resulted in decline of trade related to animal husbandry while the second was nearly impossible to monitor, making the law simply impractical.

Furthermore, the isolationist policy of the Ming Dynasty also contributed to the sinicization process in that it cut off Muslims in China from the rest of the Muslim world, hence putting a stop to direct Islamic influence from West and Central Asia. Unlike the Yuan government which opted for open-door policy to suit the need of its huge empire, the Ming emperors chose seclusion instead to prevent possible invasion from outside. Unlike before, freedom of movement was restricted which resulted in the decreasing number of Muslim migrants from West and Central Asia. Due to the closed-door policy, the people of China during the Ming period were also discouraged from going overseas. Consequently, having lost that direct or strong contact with the larger Muslim population outside the country, the Muslims in China became more inclined to blend in with the local non-Muslim majority and adopt some aspects of their culture.

Plausibly assimilation of other's culture would not be possible without the willingness of those who adopted the culture of others. In other words, apart from the racial and isolationist policies of the Ming, the Muslims themselves displayed a readiness to adopt the Han culture arguably for their own sustainability. They need to fit into the larger society, failing of which would only result in the Muslim community being alienated and casted aside. Accordingly, the Muslims in China appeared to have cautiously made the changes themselves in order to be more Chinese-like. Names similar to Chinese in sound for instance, were chosen. Muhammad was changed to Ma, Hassan to Ha, Hussain to Hu, etc. Chinese costumes were adopted to replace traditional Muslim dresses and Chinese cooking style was favoured though in choosing food ingredients the Muslims still adhered to Islamic rulings. The Muslims also began to widely use Chinese scripts in writing 
and spoke the Chinese dialects. The effect of the sinicization was also visible in the construction of mosques where elements of traditional Chinese architecture were incorporated resulting in pagoda-like mosques. Apart from avoiding ostracism, the decision to blend into the larger society also means better treatment for Muslims, if not equal to the Han Chinese, as subjects of the empire. By accommodating some aspects of the Han Chinese, this would likely ensure tolerant policy by the imperial government towards the Muslims that they would continue to be hired in the government service and military forces and allowed to practice their religion freely. Because of these reasons too, some Muslim leaders and groups fought alongside Ming forces against the invading Manchus. Following the invasion of the Ming Empire in $1644 \mathrm{CE}$, several Muslim leaders known as Ming loyalists fought against the Manchus, notable among them being Milayin and Din Guodong from Gansu. Their effort however failed as they were finally suppressed along with 100,000 followers by the invading troops (Millward 1998; Lipman 1998).

Looking at what happened in the history of relations between Muslims and majority non-Muslims in China, the desire to assimilate some aspects of Han culture by the Muslims could also possibly be due to some incidents of conflict with nonMuslims. There had been occasions where Muslims were attacked and assaulted for being foreigners or non-Chinese. One infamous incident was the massacre at Guangzhou (Canton) in $878 \mathrm{CE}$ where Muslim traders and settlers were among the 120,000 foreigners killed. Apart from Muslims, among those killed include Christians, Jews and Magians or Mazdeans (fire-worshippers). The massacre, which occurred during the Tang period, was driven by anti-foreign sentiment felt by local Chinese towards all foreigners in China, not just Muslims. Not only were foreigners seen as intruders who drained China of its wealth but also propagators of alien teachings, particularly in the case of Catholic missionaries, whose proselytising activities, were viewed to have tarnished the sanctity of Chinese soil. Due to such incidents, this might have somehow shaped the Muslims' attitude to become more accommodating towards the culture of the majority so that they were regarded as part of the larger population, hence avoiding similar prior event of mass atrocities.

\section{Synthesis of Confucianism and Islam: Gedimu School}

One of the results of the sinicization process or assimilation of Chinese culture by Hui Muslims is the synthesis between Chinese and Islamic ideas or traditions. Done by Hui intellectuals and scholars, the amalgamation between Islamic and Chinese concepts manifested in new threads of ideas that characterised a leading Islamic religious sect in China, the Gedimu. 
Belonging to the Hanafi Sunni School, the Gedimu was first introduced by Arab and Persian traders to the south-eastern coast of China in the early centuries of Islam. It is the oldest Islamic school of thought in China and remains the most dominant until now. Currently it is the largest sect with adherents distributed throughout the country. Of the current Muslim population in China, 58.2 percent belongs to Gedimu School, 21 percent Yihewani, 10.9 percent Jahriyya, 7.2 percent Khufiyya, 1.4 percent Qadariyya and 0.7 percent Kubraniyya. The name Gedimu comes from Arabic word qadim meaning "old" and in China the Gedimu is known as the "old teaching" or "old school" as opposed to later schools which appeared in the mid of the Ming era onwards. Unlike the later sects in China which are highly influenced by ideas of Middle Eastern origin such as Xiaodatang and Yahiwei, the Gedimu School which continue to exist until the present day upholds that some Confucian teachings are in line with Islamic ideas and that the two are compatible.

Several leading Muslim scholars are important to mention as they were the pioneers of the Gedimu School. Among them are Wang Daiyu, Ma Zhu, Liu Zhu and others. Apart from translating Arabic works into Chinese, the scholars were also noted for their own works on Islam in the Chinese language. Synthesising Islamic concepts with the philosophical ideas of Confucianism, Buddhism and Taoism, their works are later known as Han Kitab (Hanjin in Chinese) or Books of Han and became major religious references and reading materials on Islam for the Hui Muslims in China. Han Kitab refers to a body of Islamic literature dated from the Ming period and produced by Hui Muslim scholars in which they explained the teachings of Islam using neo-Confucian classical Chinese (Frankel 2008). In discussing the works of Gedimu scholars, this paper will be focusing on two leading figures: Wang Daiyu, considered as a pioneering scholar of the synthesis between Chinese philosophy and Islamic teaching; and Liu Zhi, the most renowned scholar of the Gedimu School. Apart from the religious works, the Gedimu is also known for its Islamic teaching method known as Jingtang Jiaoyu (means "Scripture Hall Education") which refers to a form of Islamic teaching and learning in China where Chinese characters are used to represent Arabic language and Chinese sound to pronounce Arabic. Stressing on religious education centred around the institution of mosques, religious instructions again have been somewhat influenced by Chinese culture where apart from using the Han Kitab, the students are thought to learn Arabic language in Chinese scripts and pronounce Arabic words in Chinese-like sound.

To the Gedimu scholars, it is imperative to explain Islamic concepts using classical Chinese philosophical ideas especially those of Confucianism in order to make it easier for local Muslims, many of whom were not well-versed in Arabic to understand Islam. For this purpose too, they made sure that Islamic texts and books 
were comprehensible to both Muslim and non-Muslim readers by translating Arabic books, including the holy Qur'an, into Chinese. This effort of Gedimu scholars though accepted by many Hui Muslims was rejected by a few quarters. One of the later Muslim religious groups, the Yahiwei in particular was strongly against the approach of the Gedimu School on the basis that its way of pronouncing Qur'anic verses or Arabic words in Chinese jargon or sound is improper and against Islamic tradition (Gillette 2000). Furthermore, the synthesis with Chinese philosophy of Confucianism, Buddhism and Taoism by Gedimu scholars which necessitates reconciliation between Islam and foreign ideas, as pointed out by their critics, is also in itself a form of unorthodox innovation. Moreover, while the school maintains its stance against Sufism, it too, as argued by some scholars, has absorbed some elements of Sufism, particularly of the Kubriyya throughout its centuries of existence (Frankel 2008). To understand why the reconciliation or synthesis with foreign elements - be it Sufism, Confucianism, Buddhism or Daoism - was done, one cannot but to look at the long history of Islam and Muslims in China.

After long centuries of living side by side non-Muslim Han and becoming increasingly detached from Muslim culture of West and Central Asia, the ability of Hui Muslims to use Arabic, Persian and possibly some Turkic languages, previously used by their ancestors to study Islam, gradually declined. Consequently, Islamic education or learning through the Chinese medium became necessary (Dillon 1999). The fact that Chinese, especially by the era of the Ming Dynasty, was the language used by majority of Muslims on a daily basis due to the sinicization process also means that Islamic learning and education would best be taught through that medium. Also familiar to the Muslims at that time, apart from the Chinese language were various Chinese concepts and ideas related to Confucianism, Buddhism and Taoism which were the main schools of thought in China. Many Muslim scholars had in fact during their educational training studied these Chinese concepts apart from Islamic knowledge learned at the hands of their religious teachers. Hence, given the acquaintance and familiarity of the Muslim community with these Chinese philosophical concepts and ideas, it is natural for Muslim scholars to use them in order to explain Islam.

One matter of urgency which appears to have necessitated the synthesis of Chinese and Islamic ideas is the weakening state of Islamic faith among some Muslims and poor condition of Islamic education in Ming China. While the problem was not so serious in the north-west where the Muslims there were in large number and still had their distinctive identity intact, the same cannot be said with regard to Muslims in the south-eastern coast who had been for centuries mingling with the Han community as they were mainly involved in trade and commerce. Living closely alongside the Han community coupled with their lack of sense of 
identity unlike Muslims in the northwest, the Hui in the south-eastern coast had to continuously resist assimilation into the majority non-Muslim population. It was a constant struggle that could lead to decline or loss of Islamic faith. At the same time, Islamic education too suffered as less attention or emphasis was given to the work of disseminating Islamic knowledge plus the lack of suitable materials for teaching and learning purposes. It was due to these problems that the translation works pioneered by Wang Daiyu and others were indispensable as they enabled Muslims to keep their faith and culture alive through Islamic books translated and written in Chinese scripts (Dillon 1999).

Another reason for the synthesis effort may lie in the prevailing trend among Muslim scholars elsewhere which, the Muslim scholars in China were aware of and followed suit. It was natural for scholars to look into different ideas and find points of commonalities and differences. This is what scholars do and it is no secret that in dealing with Islamic knowledge, as with other disciplines, leading Muslim scholars in West and Central Asia discussed Islam in an attractive manner referring to ideas of previous Greek, Indian philosophers, etc. For instance, famous Muslim philosophers like al-Farabi and Ibn Sina synthesised Greek ideas of Plato and Aristotle with Islam, while al-Biruni attempted to reconcile Buddhism and Islam. Following the footsteps of these great scholars, whose works had great influence on the development of various disciplines in China, it is plausible to think that scholars of the Gedimu School also attempted to relate Islam to Chinese concepts in order to attract not only non-Muslim Chinese to the religion but more importantly to ensure that the Hui Muslims understood and adhered to Islam.

Finally, the similarity between some Chinese concepts and teachings particularly of Confucianism and Islam could also explain the inclination of Gedimu scholars to synthesise both. Educated in classical Chinese studies, the Gedimu scholars such as Wang Daiyu and Liu Zhi believed that Islam and Confucianism share some commonalities and hence, are compatible. The fact that Confucianism itself is essentially a code of ethics that touches on positive values like filial piety, loyalty to rulers, benevolence, etc., made it easier for Wang Daiyu, Liu Zhi and others to come out with the synthesis since Islam too emphasises on righteous conduct of man. In the case of Liu Zhi, living during the Qing period when Confucianism was the official policy of the government and religion of China, would naturally have made him apt to study Confucianism and find ways to explain Islam using Confucian concepts. This brings to the last point - the synthesis demonstrates that Islam is aligned with mainstream intellectual Chinese culture hence projects the peaceful nature of the religion. Unlike some other foreign creeds, Islam is not a threat to popular beliefs of the Han community or a challenge to the political status quo and for this reason, the presence of Islam and Muslim communities in China, 
as argued by Gedimu scholars, is justified. This would help to ensure fair treatment of Islam and Muslims by the imperial authorities and the rights of Muslims to practice Islam in the country (Frankel 2008).

The actual synthesis between Chinese ideas and Islam first began in 16th century $\mathrm{CE}$, i.e., during the Ming period, which also marked the real process of sinicization experienced by Hui Muslims in China. Ironically, it was also the most progressive period in the long history of Islam in the country that it was known as the "Golden Age of Islam" in China. Islam increasingly spread in China while Muslims experienced a great boost due to Ming's favourable policies towards the religion and adherents of Islam. It was in the mid of the Ming era that Muslim scholars in China started to realise the need to teach Islam in a clear or understandable manner using Chinese concepts as they witnessed the decline of Islamic faith among Hui population and poor condition of Islamic education. The first move towards that direction was paved by Hu Dengzhou (1522-1597 CE), who after extensive travel found that a new approach was needed to keep Islamic faith and education alive. Consequently, he began to translate Arabic scriptures into Chinese. This technique developed by Hu Dengzhou in Shaanxi was later adopted and spread to other parts of China by Wang Daiyu and other Gedimu scholars who further improvised the method through the synthesis of Chinese concepts and Islamic teachings (Dillon 1999).

Wang Daiyu or Wang Tai-yu (1570-1660 CE) was not only a religious scholar but well-trained in the art of astronomy for which he was entrusted during the Ming era to hold the office of Master Supervisor of the Imperial Observatory. Among the first to explain Islam using Confucianism, Buddhism and Taoism, Dang Wu who was known as Zhenhui Laoren (True Old Man of Islam) also translated Islamic scriptures into Chinese scripts since he believed that such works could provide a better understanding for the Muslim community in China in comparison to Islamic works written in Arabic. Among his major works are Zhengjiao zhenquan (A True Commentary on the Orthodox Faith) in which he stressed on the consistency between the philosophy of Islam, Confucianism and Daoism, Qingzhen daxue (Islamic Great Learning) and Xizhen zhengda (Right Answers to TruthSeekers). Many of his works were used as references by later Hui Muslim scholars including Liu Zhi (Sen 2010).

A more renowned scholar of the Gedimu School is Liu Zhi, also known as Liu Jia Lian (1660-1739 CE), whose writings considered as the pinnacle of Islamic literature in China. A Muslim scholar and philosopher during the Qing era, like Wang Daiyu, Liu Zhi sought to clarify Islam and Islamic thought using Chinese concepts, borrowing terminologies from Buddhism, Daoism and particularly 
neo-Confucianism. In his famous work, Tianfang xingli (Islamic Philosophy), Liu Zhi synthesised Islamic and Chinese intellectual traditions, highlighting the similarities between some principles of Islam and those of Confucianism. Other notable works by Liu Zhi include Tianfang dianli zeyao jie (Principles of Islam) and Tianfang zhisheng shilu (Life of the Great Prophet) Wugong shiyi (On the Five Pillars), Tianfang zimu jieyi (Introduction to Arabic) and Tianfang sanzijing (Islamic 3-Character Reader) (Sen 2010). Along with the works of Wang Daiyu and other Gedimu scholars, his works formed part of the Han Kitab used by Hui Muslims in China as references until today. Apart from translating Arabic works into Chinese, he authored several hundred Chinese manuscripts on Islam and its relation to Confucianism, of which only one tenth was published.

It is worth now looking briefly at some of the synthesis made by the Gedimu scholars. What one can discern from the synthesis is that sometimes the scholars downplayed Islamic concepts or ideas so as to ensure that they are in line with those of Chinese schools of thought. This is understandable since they wanted to position Islam within a broader context of Chinese tradition which prevailed throughout the country. For instance, Liu Zhi considered Confucius and Mencius of Confucian School as "Sages of the East" while Prophet Muhammad (pbuh) as "Sage of the West" instead of highlighting the prophet-hood of the latter. To them, the teachings of Confucius, Mencius and Prophet Muhammad (pbuh) despite some variances all rooted in the same divine source of wisdom and moral order (Frankel 2008). For the same reason to accentuate the commonalities between Islam and Confucianism, the Muslim scholars abstained themselves from lengthy discussion on Islamic law (shari'a) thus signified the readiness of the Muslim community to adhere to the law of the land that is the imperial law, except in matters related to individual or communal religious practices (Frankel 2008).

Another aspect emphasised by the Gedimu scholars was the harmonious relation between Confucian code of ethics and Islamic teachings. They took the view that the "Five Cardinal Relationships" which form the foundation of Confucian social order are compatible with Islam as they also characterised the duties and responsibilities of a good Muslim. The five main relationships are the relationships between foreign (ruler) and subject, father and son, husband and wife, elder and younger brother, and between friends (Frankel 2008). Underlying these relationships are positive values like filial piety, loyalty, brotherly love, benevolence, etc.

Indeed, Islam's emphasis on good values made it easy for the Gedimu scholars to take up the view that Confucian teachings with respect to the Five Relationships are compatible with Islam. In the context of the relationship between ruler and subjects for instance, the scholars maintained that the Muslims were allowed to 
believe in the Chinese political concept of T'ien Ming or "Mandate of Heaven". It was a traditional Chinese concept which dates back to the Chou era (1115-221 BC) where the Chinese believed that their emperors were entrusted by heaven or gods to rule wisely and that the people accordingly were to fully submit to their rulers. If a ruler failed to carry out his responsibility, the heaven will withdraw the mandate and invest it on another person. The concept essentially entails full loyalty to the Chinese emperor and this, in the view of Gedimu scholars, is to be accepted by Muslims in the country since Islam too, they argued, enjoins its followers to obey appointed rulers whether Muslims or non-Muslims, as long as they ruled based on the principle of justice (Frankel 2008).

This leads to the issue of leadership which in Islam the concept of ulil amri (leaders) stands out as one requirement for a good and functional society. While there are many debatable views on the meaning of ulil amri among Muslim scholars, whether they could be Muslims or non-Muslims, or must be Muslim leaders who abide by Islamic law, it seems that the Gedimu scholars opted for a simple definition of the concept. By doing so, the factor of religiosity of leaders was de-emphasised, hence making it easier to call Muslims in China to submit their loyalty to Chinese authorities that is by adhering to the T'ien Ming concept. Given the condition which the Muslims in that country were in, being a minority group among the majority non-Muslim population, it is only logical that the Gedimu scholars adopted such a view. Not only did this help to ensure peace prevailed in the country, but more importantly warranted general acceptance and tolerant treatment towards the Muslim minority by Chinese imperial authorities.

\section{Conclusion}

The sinicization of Muslims was indeed a gradual process that took centuries to produce significant results. Beginning from the time when Islam was first introduced to China in the 7th century, the assimilation of Chinese culture by Hui Muslims accelerated during the Ming era. The process which was prompted by wide-ranging sociocultural and political factors, albeit not fully, no doubt had lasting impact on the Muslim minority in China that changes took place in different aspects of their lives. One of such lasting impacts of sinicization is the formation of the Gedimu School which was essentially the synthesis of Chinese and Islamic ideas and traditions. Through the works of Gedimu scholars such as Wang Daiyu and Liu Zhi, Islam and Muslims in imperial China were treated well by the Chinese authorities despite being a minority religion and group. Not only did the synthesis highlight the universality of Islam as a religion that is suited to different eras and places, but also helped to ensure the survival of Islam in China until present day. 


\section{References}

Buell, P.D. 1979. Sino-Khitan administration in Mongol Bukhara. Journal of Asian History 13(2): 121-151. Wiesbaden: Harrassowitz Verlag.

Dillon, M. 1996. China's Muslims (Images of Asia). Hong Kong, Oxford and New York: Oxford University Press.

1999. China's Muslim Hui community: Migration, settlements and sects. Richmond: Curzon Press.

Fairbank, J.K. and Liu, K-C. 1980. The Cambridge history of China (vol. 2, part 2). New York and Melbourne: Cambridge University Press.

Fairchild, H.P. 1944. Dictionary of sociology. New York: Philosophical Library.

Frankel, J.D. 2008. Apolitization: One facet of Chinese Islam. Journal of Muslim Minority Affairs 28(3): 421-434. https://doi.org/10.1080/13602000802548078

Gillette, M.B. 2000. Between Meccas and Beijing: Modernization and consumption among urban Chinese Muslims. California: Stanford University Press. https://doi. org/10.2458/v9i1.21637

Gunaratna, R., Acharya, A. and Pengxin, W. 2010. Ethnic identity and conflict in China. New York: Palgrave Macmillan. https://doi.org/10.1057/9780230107878

Israeli, R. 2002. Islam in China: Religion, ethnicity, culture and politics. Lanham and Oxford: Lexington Books.

Junqing, M. 2010. The present situation and characteristics of contemporary Islam in China. JISMOR, 8. Islam by province. http://doors.doshisha.ac.jp/dnar/repository/ ir/18185/r002000080004.pdf (accessed 7 August 2017).

Leslie, D.D. 1981. Islamic literature in Chinese, late Ming and early Ch'ing: Books, authors and associates. Belconnen: Canberra College of Advanced Education. https://doi.org/10.1017/s0035869x00159738

1998. The integration of religious minorities in China: The case of Chinese Muslims (vol. 59 of George Earnest Morrison Lecture in Ethnology). Canberra: Australian National University Press.

Lipman, J.N. 1997. Familiar strangers: A history of Muslims in Northwest China. Seattle and London: University of Washington Press. https://doi.org/10.1086/ahr/105.1.190

Millward, J.A. 1998. Beyond the pass: Economy, ethnicity, and empire in Qing Central Asia, 1759-1864. California: Stanford University Press. https://doi.org/10.24201/ eaa.v53i3.2373

Owadally, Y. 2006. The book of a great sahabi: Sa'ad Ibn Abi Waqqas (r.a.) and Muslims in China. Kuala Lumpur: A.S. Nordeen.

Petersen, K. 2018. Interpreting Islam in China: Pilgrimage, scripture and language in the Han Kitab. New York: Oxford University Press.

Sen, T.T. 2010. Cheng Ho: Penyebar Islam dari China ke Nusantara. Jakarta: Penerbit Buku Kompas.

Tontini, R. 2016. Muslim Sanzijing: Shifts and continuities in the definition of Islam in China. Leiden and Boston: Brill.

Wain, A. 2017. Liu Zhi: A leading Chinese Muslim scholar and saint. http://www.iais.org. my/e/attach/Liu_Zhi.pdf (accessed 8 August 2017). 